Policy Research Working Paper 2837

\title{
Reform, Growth, and Poverty in Vietnam
}

\author{
David Dollar
}

The World Bank

Development Research Group

Macroeconomics and Growth

May 2002 
Policy Research Working Paper 2837

\section{Abstract}

Vietnam grew rapidly in the 1990 s, and yet by many measures it has poor economic institutions. Dollar seeks to explain this apparent anomaly. Between the 1980s and 1990s Vietnam carried out significant economic reforms, notably stabilization, the introduction of positive real interest rates, trade liberalization, and initial property rights reform in agriculture. Relating these changes to the empirical growth literature, the author finds that Vietnam's growth acceleration is about what would be predicted. Conditional convergence also suggests that the country's high growth rate will decelerate unless further reforms are taken.
Dollar then looks at the level of institutional and policy development in Vietnam compared with other emerging market economies. While Vietnam's policies have improved, they did so starting from a very low base. So, it can be simultaneously true that Vietnam's policies have improved a lot and yet are rather poor in comparative perspective. A comparison of governance indicators, financial sector issues, and the infrastructure of international integration reveals serious institutional weaknesses in Vietnam that need to be addressed if a high growth rate is to be sustained.

This paper-a product of Macroeconomics and Growth, Development Research Group-is part of a larger effort in the group to study household welfare and poverty reduction in Vietnam. Copies of the paper are available free from the World Bank, 1818 H Street NW, Washington, DC 20433. Please contact Emily Khine, room MC3-301, telephone 202-473-7471, fax 202-522-3518, email address kkhine@worldbank.org. Policy Research Working Papers are also posted on the Web at http://econ.worldbank.org. The author may be contacted at ddollar@worldbank.org. May 2002. (33 pages)

The Policy Research Working Paper Series disseminates the findings of work in progress to encourage the exchange of ideas about development issues. An objective of the series is to get the findings out quickly, even if the presentations are less than fully polished. The papers carry the names of the authors and should be cited accordingly. The findings, interpretations, and conclusions expressed in this paper are entirely those of the authors. They do not necessarily represent the view of the World Bank, its Executive Directors, or the countries they represent. 


\title{
Reform, Growth, and Poverty in Vietnam
}

\author{
David Dollar
}

\section{Development Research Group, World Bank}

1818 H Street N.W., Washington, DC, 20433 (ddollar@worldbank.org). This paper was presented at the workshop on "Economic Growth and Household Welfare: Policy Lessons for Vietnam," Hanoi, May 16-18, 2001, and benefits from helpful comments there and from Paul Glewwe and Nisha Agrawal. I am grateful to the Research Support Budget for financial assistance and to Ximena Clark and Pablo Zoido-Lobaton for excellent research assistance. 



\section{Introduction}

Vietnam has been one of the fastest growing economies in the world in the 1990s, and yet by many conventional measures it has poor economic policies. In the Index of Economic Freedom, 2000, for example, Vietnam is ranked $144^{\text {th }}$ out of 155 countries on this measure that is supposed to capture the environment for investment and growth. (This index from the Heritage Foundation may not be an unbiased assessment of Vietnam's investment climate, but its low rating of Vietnam is mirrored in other indicators that we will take up in section 4.) The objective of this paper is to explain this apparent anomaly, and to do so in a way that provides useful guidance to policy-makers in Vietnam about what institutional and policy reforms are needed for sustained growth and poverty reduction.

The next section provides a framework for addressing this problem by briefly reviewing modern growth theory and the empirical growth literature. I stress the empirical results on important institutions and policies for growth, as well as the phenomenon of conditional convergence. Policy improvements generally lead to growth accelerations, but without further reform the growth rate will then tend to slow down over time.

Section 3 then examines a number of indicators of Vietnam's reform between the 1980 s and 1990s, notably the macro reforms of stabilization, positive real interest rates, trade liberalization, and initial property rights reform in agriculture. Relating these changes back to the empirical growth literature, I estimate what growth effect Vietnam 
should have gotten from its reform and what in fact transpired, to see if its performance really is an anomaly.

In the fourth section I look at the level of institutional and policy development in Vietnam, compared to other emerging market economies. While Vietnam's policies have improved, they did so starting from a truly low base. Hence, it can be simultaneously true that Vietnam's policies have improved a lot and yet are rather poor in comparative perspective. A comparison of governance indicators, financial sector issues, and the infrastructure of international integration reveals serious institutional weaknesses in Vietnam that need to be addressed if a high growth rate is to be sustained. Section 5 briefly sums up.

\section{Determinants of Long-term Growth}

There is a vast empirical literature that investigates the determinants of growth. Much of this was spurred by the endogenous growth theories of Romer (1986) and Lucas (1986). The new growth models emphasized the importance of creating a good environment for firms to innovate - either through R\&D to generate truly new products or processes or through transfer or imitation of advanced technologies from other countries, which is a type of innovation for the local economy.

Researchers have looked at a wide range of different variables that may affect growth. One needs to approach this cross-country empirical literature with some caution. The number of countries in the world is not that large, so that this work uses relatively small samples. Many of the variables that researchers have looked at are correlated among themselves, so that it is difficult to identify the effects of different policies 
precisely. And there are issues of which way the causality runs. Nevertheless, this empirical literature is useful for summarizing important patterns in the growth data.

Empirical studies of growth are based on the following "standard" cross-country growth regression:

$$
y_{c t}=\beta_{0}+\beta_{1} \cdot y_{c, t-k}+\beta_{2}^{\prime} X_{c t}+\eta_{c}+\gamma_{t}+v_{c t}
$$

where $y_{c t}$ is log-level of per capita GDP in country $c$ at time $t, y_{c, t-k}$ is its lag $k$ years ago $\left(\mathrm{k}=10\right.$ years in my application using decadal data) and $\mathrm{X}_{\mathrm{ct}}$ is a set of control variables which are measured as averages over the decade between $t-k$ and $t$. Subtracting lagged income from both sides of the equation gives the more conventional formulation in which the dependent variable is growth, regressed on initial income and a set of control variables. The disturbance term in the regression consists of an unobserved country effect that is constant over time, $\eta_{c}$, an unobserved period effect that is common across countries, $\gamma_{t}$, and a component that varies across both countries and years which we assume to be uncorrelated over time, $\mathrm{v}_{\mathrm{ct}}$.

Most of the early empirical studies considered growth over a very long period $(k=25$ years or more) so that there is only one observation per country. As a result, all of the effects of interest are estimated using only the cross-country variation in the data. Some papers consider shorter periods such as decades or quinquennia, and typically combine the cross-country and within-country variation in the data in a fairly ad-hoc manner. Caselli, Esquivel and Lefort (1996) provide a useful critique of conventional panel growth econometrics and a proposed solution, which is to estimate equation (1) in differences, using appropriate lags of the right-hand side variables as instruments. In particular, they advocate estimating the following regression:

$$
y_{c t}-y_{c, t-k}=\beta_{1} \cdot\left(y_{c, t-k}-y_{c, t-2 k}\right)+\beta_{2}{ }^{\prime}\left(x_{c t}-x_{c, t-k}\right)+\left(\gamma_{t}-\gamma_{t-k}\right)+\left(v_{c t}-v_{c, t-k}\right)
$$

This is nothing more than a regression of growth on lagged growth, and on changes in the set of explanatory variables. Or, subtracting lagged growth from both sides of the 
equation, we have changes in growth from one decade to the next as a function of initial growth and changes in the explanatory variables. ${ }^{1}$ Much of the recent work on growth adopts this approach, which has the advantage of controlling for country-specific effects that do not change over time.

I would point to five results that are fairly robust in the growth literature. First, Fischer (1993) and others find that high inflation is bad for growth. This seems a commonsense result that is hard to dispute. To some extent inflation reflects shocks and other things beyond the government's control, but truly high inflation (above say $40 \%$ ) obviously reflects monetary mismanagement. In addition, there is a pretty clear negative relationship between government consumption and growth, first noted by Easterly and Rebelo (1993). Some government recurrent expenditures are socially productive, but countries with very high government spending usually have inefficient bureaucracies and high levels of corruption. A number of studies, most recently Frankel and Romer (1999) and Dollar and Kraay (2001b), find that openness to trade and direct foreign investment accelerates growth. These latter findings are very much in the spirit of the new growth models, which emphasize the importance of the size of the market for creating a fine division of labor and stronger incentives to innovate.

In addition to macro and trade policies, financial development is also a spur to growth [Levine, Loayza and Beck (2000)]. Countries that have more developed stock markets and/or deeper banking systems tend to growth fast, after controlling for other variables. Finally, measures of the strength of property rights, rule of law, or level of corruption are highly correlated with growth [Kaufmann, Kraay, and Zoido-Lobatón (1999); Knack and Keefer (1995)]. The existing measures of property rights or

\footnotetext{
${ }^{1}$ Elaborations of these techniques involve jointly estimating a system of two equations, in levels (Equation 1 ) and in differences (Equation 2), and using lagged changes of endogenous variables as instruments for levels in the former
} 
corruption come from surveys of private businesses and reflect the extent to which investors perceive there to be problems with harassment, corruption, and inefficient regulation.

There are lots of other variables that researchers have used in empirical studies of growth. There are some studies that link infrastructure deficiencies in telecommunications or power to poor growth performance (for example, Easterly and Levine, 1999). However, my reading of the evidence is that those variables are not that robust if one also controls for all of the institutions and policies noted above. I see infrastructure provision as the result of good public institutions and policies.

So, while there remain disputes about the importance of individual policies, in general there is broad agreement among economists that growth is promoted by the policy package of private property rights, sound rule of law, macro stability, government spending that is not excessive and well focused on public goods, and openness to foreign trade and investment.

A final important result from the growth literature is "conditional convergence." Holding institutions and policies constant, there is a tendency for the growth rate to slow down over time. This result also means that, cross-sectionally among a group of economies with similar institutions and policies, poorer ones will grow faster and hence "converge" on the richer ones. This convergence can be seen, for example, among OECD countries. The relatively poor ones in 1960 (Japan, Italy) grew rapidly in 1960s and 1970 s, but then their growth rates slowed. The growth rate of the productivity leader, the U.S., has been fairly stable at about $2 \%$ per capita per year. As a result of this

(Arellano and Bover (1995)). This approach can yield important efficiency gains (Blundell and Bond (1998)). 
convergence among OECD economies, the overall growth rate of the rich world has slowed decade by decade, and in the 1990 s was at about $2 \%$ (figure 1 ).

A growing number of developing countries have moved on this growth-oriented agenda in the past fifteen years, and in general they have gotten good results from reform. For example, Dollar and Kraay (2001b) identified a group of "strong globalizers" (the top one-third of developing countries in terms of increased participation in international trade over the past two decades). By construction this group has had a particularly large increase in trade: $104 \%$, compared to $71 \%$ for the rich countries. What is striking is that the remaining two-thirds of developing countries have actually had a decline in trade to GDP over this period (figure 2). The globalizing group has also cut import tariffs significantly, 34 points on average, compared to 11 points for the non-globalizers (figure 3). The list of post-1980 globalizers includes some well-known reformers (Bangladesh, China, Hungary, India, Malaysia, Mexico, the Philippines, and Thailand). These countries have been moving on the broad policy agenda outlined above. These recent globalizers have experienced an acceleration of their growth rates, from $1.4 \%$ per year in the $1960 \mathrm{~s}$ to $3.5 \%$ in the $1980 \mathrm{~s}$, and $5.0 \%$ in the $1990 \mathrm{~s}$ (figure 4), while rich country growth rates slowed down over this period. What about developing countries not in the "globalizing" group? They had a decline in the average growth rate from $3.3 \%$ per year in the 1970 s to $0.8 \%$ in the 1980 s and $1.4 \%$ in the 1990 s (figure 5 ).

While there has been growing consensus over the past few years about what policies are good for growth, at the same time the old debate about growth and inequality has resurfaced. It is common to hear claims that this era of globalization is leading to mounting inequality within countries, so that growth is not benefiting the poor. [For 
example: "Globalization has dramatically increased inequality between and within nations..."--Jay Mazur, "Labor's New Internationalism," Foreign Affairs (Jan/Feb 2000).] Neither part of this claim is true. The growth data presented above show that developing countries that are strongly embracing globalization are the big winners from globalization. The globalizing developing countries grew at $5.0 \%$ in the $1990 \mathrm{~s}$ and hence converged on the rich countries, growing only at $2.2 \%$ (figure 6 ). It is the developing countries that are not embracing globalization that are being left behind.

What about the claim that globalization and growth in general lead to higher inequality within countries? In order to test whether growth is associated with higher inequality within countries (that is, is biased against the poor), Dollar and Kraay (2001a) put together a large data set on income inequality, compiled from a variety of existing sources (primarily the dataset constructed by Deininger and Squire (1996)) with several updates using more recently available data). The data consist of Gini coefficients for a large number of countries and years, and five points on the Lorenz curve for most of these country-year observations. As noted by these and other authors, there are substantial difficulties in comparing income distribution data across countries. Countries differ in the concept measured (income versus consumption), the measure of income (gross versus net), the unit of observation (individuals versus households), and the coverage of the survey (national versus subnational). Dollar and Kraay restrict attention to distribution data based on nationally representative sources identified as high-quality by Deininger and Squire (1996), and perform some simple adjustments to control for differences in the types of surveys. These data cover a total of 137 countries. 
Dollar and Kraay use these data to try to understand what is happening to the income of the bottom $20 \%$ of the income distribution, as globalization proceeds. There is a one-to-one relationship between the growth rate of income of the poor and the growth rate of per capita income, but also quite a lot of variation around that average relationship (figure 7). In other words, percentage changes in incomes of the poor on average are equal to percentage changes in average incomes. A useful way of interpreting these results is to realize that they are equivalent to the finding that changes in the distribution of income are not systematically associated with the growth rate.

Can we explain deviations around the one-to-one relationship, which reflect changes in inequality? The hypothesis that greater trade openness leads to growing household inequality is the hypothesis that growing openness leads to points "below the line" in figure 7: growth of income of the poor less than proportionate to per capita GDP growth. Dollar and Kraay considered a variety of possible variables that might explain cross-country differences in the extent to which growth accrues to those in the bottom quintile, with little success. One of the variables considered was trade volumes, but Dollar and Kraay found no evidence whatsoever of a systematic relationship between changes in trade and changes in inequality. There is simply no association between changes in trade to GDP and changes in the Gini measure of inequality (figure 8). No doubt trade and investment liberalization has distributional consequences - that is, there are "winners" and "losers" in the short run. However, our finding is that the losers do not come disproportionately from the poor. While it is heartening to know that the losers do not come disproportionately from the poor, nevertheless it has to be a concern that some poor households are hurt in the short run by trade liberalization. It is thus important to 
complement open trade policies with effective social protection measures such as unemployment insurance and food-for-work schemes. (Closed economies obviously need safety nets as well since households are subject to shocks from business cycles, technological change, weather, and disease.) To the extent that trade openness raises national income, it strengthens the fiscal ability of a society to provide these safety nets.

The fact that increased trade generally goes hand-in-hand with more rapid growth and no systematic change in household income distribution, means that increased trade generally goes hand-in-hand with improvements in well-being of the poor. Dollar and Kraay (2001a) similarly examine whether or not other institutions and policies that are good for growth, tend to affect inequality. For trade openness, rule of law, and financial development, the distribution effects are all very small and not significantly different from zero. In the case of government consumption and inflation, there are more significant distributional effects. In general, high inflation and large government consumption are especially bad for the poor. Such policies create a poor environment for growth and tend to harm the poor disproportionately. Based on empirical evidence we can reject the view that growth-enhancing policies, including integration with the global economy, do not work for the poor.

\section{Vietnam's Experience with Reform in the 1990s}

Cross-country growth analysis is useful for summarizing what is true in general or on average. However, individual country experiences can vary a lot from what would be expected or predicted from the cross-country regressions. In this section I look at some indicators of Vietnam's reform between the 1980s and 1990s and ask whether or not the 
country got the expected boost in growth or whether it is an anomaly in either direction (higher or lower growth than would be predicted).

There is a growing descriptive literature of Vietnam's economic reform (Dapice 1995; de Vylder and Fforde 1996; Dollar 1994; Ljunggren 1993; Le Dang Doanh 1995). It is widely recognized that stabilization from high inflation was one key aspect of the reform. The inflation rate declined from over 160 percent per annum in 1988 to less than 10 percent in 1997 (figure 9). This stabilization was the result of fiscal adjustment and monetary restraint in the early 1990 s.

Together with the stabilization there were some initial financial sector reforms, raising interest rates to positive real levels and introducing some element of competition into the system. A measure of financial development that has been used in the growth literature is commercial bank assets relative to total bank assets. In Vietnam this measure of financial development increased from 0.64 in 1992 to 0.83 in 1997 (unfortunately the data are not available before 1992).

Liberalization of foreign trade and investment has been an important part of Vietnam's reform. The trade system was highly restricted through the mid-1980s. Reform has included dismantling of non-tariff barriers and tariff reductions (Dollar and Ljunggren 1997). It is difficult to measure the extent of trade policy reform. One good indicator is the volume of trade in constant prices relative to PPP GDP. This ratio increased from .08 in 1989 to .27 in 1997 . In today's world trade is closely related to foreign investment. Vietnam also liberalized its policies toward foreign investment. Flows of FDI averaged more than 5\% of GDP in the second half of the 1990s, up from virtually zero in the 1980 s. 
Some of the most import reforms in Vietnam involved strengthening of property rights. The initial land reform gave use rights over land to peasant families, and in practice there is quite an active market in land. Company law and foreign investment law improved the property rights over plant and equipment. It is hard to measure this change in the extent of property rights. In the next section I am going to introduce a measure of the strength of property rights across countries in the late 1990s. This measure shows Vietnam to be significantly better than nearby Burma. For purposes of making a quantitative estimate, I am going to assume that the property rights reform in Vietnam between the late 1980s and the late 1990s was equivalent to the current distance between Burma and Vietnam in this regard. I recognize that this is an hoc approach, but I think it will shed some light on the importance of property rights reform in Vietnam's experience to date.

If we take the changes in figure 9 as crude indicators of the major reforms that have taken place in Vietnam, what would we estimate the effect of reform to be, in light of the empirical growth literature? In figure $10 \mathrm{I}$ take the point estimates from recent panel growth regressions (Dollar and Kraay, 2001a, 2001b) and apply them to the changes in policies observed in Vietnam. The result is that trade liberalization is estimated to account for an increase in the growth rate of 1.3 percentage points; disinflation, 1.5 percentage points; financial deepening, 1.8 percentage points; and property rights reform, 2.6 percentage points. These are each independent effects: the total effect of these reforms would thus be an increase in the growth rate of 7.2 percentage points. 
One should of course take these point estimates.with a certain amount of skepticism. Yet, it is interesting that the estimated effect of reforms from the crosscountry growth literature accords quite well with Vietnam's experience. It should have gotten a large boost in growth, and in fact it did. For much of the 1980s the real per capita growth was zero; for the $1992-98$ period it was $5.4 \%$. The world growth rate slowed down by about one point between the 1980s and 1990s. So, relative to the world growth rate, Vietnam's growth rate accelerated by about 6.4 percentage points, quite similar to what would have been expected from its reforms based on the empirical growth literature.

So, Vietnam has gotten the expected results from economic reform, in terms of growth. What about developments in inequality and poverty? Here too it turns out that Vietnam is typical. In the last section, I noted that in general there is no strong relationship between the kind of reforms that Vietnam has carried out and changes in household income inequality. The VNLSS survey in 1992 found relatively low inequality in Vietnam (Gini of .35), and the follow-up survey in 1998 found essentially the same degree of inequality.

Thus, reforms in Vietnam have led to a dramatic increase in income of the poor. The poverty headcount rate (based on a 2000 calorie poverty line) declined from $75 \%$ of the population in 1988, to $58 \%$ in 1993, and $37 \%$ in 1998 (figure 11). Poverty was cut in half in a decade. It is interesting to put Vietnam's poverty reduction experience in perspective by comparing it with China's and India's. In both China and India reform has coincided with mounting inequality, hampering the extent to which growth has translated into poverty reduction (figure 12). While Vietnam's growth rate has been 
distinctly lower than China's, its rate of poverty reduction has been nearly the same. (This mapping from growth to poverty reduction depends not only on changes in the distribution of income, but also on the initial level of per capita income and the initial degree of inequality.)

Thus, the story so far on Vietnam has been quite positive. There were large improvements in policies between the 1980s and the 1990s, an acceleration in growth, and a dramatic decline in poverty. But now I am going to throw some cold water on the discussion, by reminding the reader about conditional convergence. Vietnam started out in the 1980 s as an extremely poor country with extremely poor policies. In that context some modest reforms were large improvements in policies, and, starting from an extremely low base, Vietnam was able to growth extremely rapidly. However, if policies remain the same, Vietnam's growth rate will slow down as it gets richer. Dollar and Kraay (2001b) estimate a convergence coefficient of .67: that is, a per capital growth rate of $6 \%$ in one decade, will be $4 \%$ in the next, as long as policies remain the same (figure 13). So, in the next section, I turn to the question of the level of Vietnam's policies, compared to other emerging market economies. This comparison is a useful way of highlighting key areas in which Vietnam needs to move in its reform if it is to sustain a high growth rate.

\section{Vietnam Compared to Other Emerging Markets}

In this section I will focus on the level of policies in Vietnam in the late 1990s, comparing it to other emerging markets in the areas of property rights/governance, financial and labor markets, and openness to foreign trade and investment. 


\section{Property rights/governance}

Kaufman, Kraay and Zoido-Lobaton (1999) combine dozens of indicators from 13 sources under 5 categories that measure broad dimensions of governance. The categories include:

- Government effectiveness measures bureaucratic delays, competence of officials, the quality of public service delivery and the independence of the civil service from political pressures. This grouping of indicators covers the elements needed for the government to design and implement good policies.

- Regulatory burden includes the numbers of regulations within a market, the number of markets that are regulated, competition policy measures, and price controls. This captures more of the outcomes of the policies and provides a sense of how marketfriendly the investment climate is.

- Rule of law captures the extent of crime, property rights, tax evasion and the legal system's effectiveness. It indicates the enforceability of contracts and the predictability of rules.

- Graft measures include the frequency and size of irregular payments.

- Political instability and violence measures the incidence of coups, assassinations, riots, and armed conflicts and provides a measure of the likelihood of a violent overthrow of a governing party.

The political instability measure is primarily concerned with the probability of violent shifts in political power rather than constitutionally sanctioned shifts in policy stance.

The other four are highly correlated, with correlations of 0.69 to 0.93 . These indicators capture different dimensions of property rights: basic contract enforcement and the rule of law, political stability and freedom from violence; freedom from corruption. At first glance the link from the other two measures - government effectiveness and regulatory burden - to property rights may not be obvious. But together they capture the extent to which there is an efficient division of labor between the public and private sectors, where an inefficient division leads to poor use of resources both in the public sector and in the private. 
Figure 14 shows governance in Vietnam and four other Asian countries (Burma, China, India, and Thailand). The way to read these "governance pentagons" is as follows: for each indicator, the mean for all countries in the world is zero and the standard deviation is 1 . Thus, Vietnam is perceived to have above average political stability, but to be well below average on the other four dimensions of governance. In terms of basic property rights and rule of law, Burma is very poor (and it is that Burma level that I took as an estimate of Vietnam's situation circa 1986). Vietnam is about half a standard deviation better than Burma, but significantly worse than China or India. Thailand in turn is significantly better than China or India. (Countries in the developing world that score really high on this measure are Chile and Singapore; in making comparisons, I am concentrating on countries that are not too far from Vietnam's level of development.)

In terms of regulatory framework for business and government effectiveness in providing services, Vietnam also lags significantly behind China and India. In terms of corruption, China, India, and Vietnam are all perceived to be about the same.

Because these are indexes, it is not easy to interpret these differences. The measures of rule of law, regulatory burden, and government effectiveness are highly correlated. For all of them Vietnam lags China by about half a standard deviation. In growth analysis, that is a large difference that is "worth" about 2-3 percentage points in growth.

Factor markets

Another useful source of comparative information is the Global Competitive Report, which ranks a large number of countries in terms of different dimensions of 
competitiveness. These are subjective assessments of the international business community and should be treated with some caution. Still, it is interesting to see that Vietnam is ranked among the lowest of the countries rated (figure 15). Vietnam is seen to be far less competitive than China (which is in the middle of the pack). Two areas that are singled out as particular weaknesses in Vietnam are financial markets and labor markets.

Vietnam made an initial set of reforms in the financial sector, but then has done little in the past five years to follow up. The banking sector is still dominated by a few, poorly managed state banks. Much of the outstanding credit of these institutions is to state-owned enterprises. Some of the SOEs, especially those working with foreign partners, are doing well, but many are in financial difficulty. Hence, the financial sector is saddled with a large degree of non-performing loans. This results in high spreads and poor ability to channel funds to the most productive investments. To the extent that all of this is explicitly or implicitly backed by the government, it also represents a contingent liability that weakens the government's fiscal position. A similar situation prevailed in Thailand before its 1997 financial crisis. The government's fiscal situation looked good on the surface; however, it was the guarantor of a risky and poorly managed financial system. A modest shock then precipitated a large financial and exchange rate crisis (Burnside, Eichenbaum, and Rebelo, forthcoming). Vietnam has a relatively closed capital account, but it would be naïve to think that this alone will insulate it from a potential financial/currency crisis. As Vietnam's economy develops and is more integrated with the global economy on the real side (trade and direct investment), it becomes increasingly difficult to maintain capital controls. Thus, reforming the financial 
system is a high priority both to help create a good environment for growth and to provide insurance against a financial/currency crisis that would really set back the country's development.

\section{Openness}

Vietnam has been negotiating to join the WTO, and that process has revealed that the country still has significant barriers to trade. Following through on its plans to join the WTO will require addressing these issues. But here I want to stress a different aspect of openness. Participating more in the global economy has been an important part of Vietnam's success to date. But to deepen that participation will require not only trade reforms, but also improvements in both the hard and soft infrastructure of trade: ports, customs administration, insurance, and finance. There are indicators that Vietnam is lagging behind competitors in these key areas.

Take shipping costs, for example, for which we have good data on all of the shipments into the United States. For shipments of garments in 1998, the shipping cost from Saigon to the west coast of the U.S. was nearly $10 \%$ of the value of the shipment, compared to $4 \%$ for similar shipments from Shanghai or Bangkok (figure 16). There are small variations in the distances from these different cities to the U.S., but they cannot explain the variations in shipping costs (Saigon is actually closer than Bangkok to the U.S.) Rather, these differences result to a large extent from the level of port efficiency, which leads to delays and high costs in the case of Vietnam. The shipping cost differences for textiles are even more striking (figure 17).

In the case of garments, Vietnam has great potential as a producer and exporter, especially as it joins the WTO and the multi-fibre arrangement is phased out. Now, the 
shipping cost difference between Saigon (nearly 10\%) and Shanghai (4\%) may not seem like much, but here is what it means to a producer. The wholesale price of an ordinary men's shirt landed in Long Beach is about $\$ 1$. The value added in that shirt is about 50 cents, of which half would be labor cost in a country such as Vietnam. Thus, there is a potential profit of about 25 cents. Given the low capital requirement of the sector, this should be a highly profitable and hence expanding industry in Vietnam. Thus, the fact that it costs six cents more to ship a shirt from Saigon to Long Beach, than from Shanghai to Long Beach, is not a trivial difference. The entrepreneur loses six of 25 cents of potential profit just from that one bottleneck alone. If there are other bottlenecks in domestic transport (to get to the port) or in customs administration to get inputs into and outputs out of the country, then each of these will be an additional "tax" eroding further that potential profit.

Thus, in comparing Vietnam with other emerging market economies we find a number of deficiencies in the investment climate that will influence investment and growth. The underlying weaknesses are institutional, concerning the protection of property rights and efficient regulation of markets, the supervision of the financial system, and the policy framework for infrastructure development. Vietnam's reforms initially attracted quite a lot of enthusiasm from foreign investors. In 1998 the level of foreign direct investment, relative to GDP, was comparable in Vietnam to other emerging markets, such as Brazil and China, though well behind Malaysia, Thailand, or Malaysia (figure 18).

The time trend of foreign investment into Vietnam, however, raises some concerns. Volumes rose sharply from 1990 through 1995, but then leveled off and 
declined (figure 19). One might think that the decline in 1998 was partly related to the overall East Asian financial crisis. However, direct foreign investment worldwide actually increased during the crisis years (while portfolio flows dropped sharply). Hence, in an overall improving global climate for direct investment, Vietnam has been getting diminished attention from investors.

\section{Conclusions}

In the 1990s Vietnam was one of the fastest growing economies in the world, and at the same time the level of institutions and policies in Vietnam was poor compared to other emerging market economies. These two, apparently discordant facts can be reconciled within the framework of modern growth theory and evidence. The key to the apparent anomaly lies in Vietnam's initial conditions in the mid-1980s. The country has a good location and good human resources. However, in the mid-1980s it had truly terrible economic policies that translated into an extremely low per capita income. Starting from such a base, a modest set of initial reforms will have a large impact and generate a very high growth rate (especially in a good location, such as Vietnam's). The initial reforms are also quite feasible technically for a low-income country. They involve macroeconomic policy changes such as price liberalization, devaluation, trade liberalization, and interest rate increases. Vietnam also carried out land reforms in agriculture that were important, but that were also not difficult technically (essentially returning land to peasant families). All of these reforms require political will, but are not difficult technically. 
Hence, Vietnam received the kind of growth boost that is to be expected from an initial set of macro reforms in a low-income environment. But, another well established empirical regularity of the growth literature is conditional convergence: holding policies constant, there is a tendency for the initially high growth rate in a low-income country to slow down as it develops. Thus, the key to sustained high growth over several decades is continual upgrading of economic institutions and policies: legal reform, regulatory improvements, deepening of the financial system, regulation that allows efficient infrastructure investment and thus reduces transactions costs. The highly successful economies such as Taiwan (China) demonstrate this kind of continual improvement over several decades.

The slowdown in foreign investment into Vietnam and the fact that its growth rate remains well below that of neighboring China suggests that Vietnam has not followed its initial reforms with sufficient institutional upgrading. These institutional dimensions are hard to measure, but there are various indicators that are informative. I have presented a number of these, painting a consistent picture of weaknesses in Vietnam's governance, financial sector, and transport infrastructure that point to important areas in need of further reform. Without these reforms, we can expect Vietnam's growth rate to decelerate. So, a balanced assessment of Vietnam in the 1990s is that initial successful reforms produced goods results and have led to an important decline in extreme poverty. However, there has been some tendency for the government to rest on its laurels in recent years, leading to a decline in investment and growth. For Vietnam to keep up with other competitive economies in its region, the government will have to get back on the reform horse. 


\section{References}

Ades, Alberto and Edward Glaeser (1999). "Evidence on Growth, Increasing Returns, and the Extent of the Market". Quarterly Journal of Economics. 114(3):10251046.

Arellano, M. and O. Bover (1995). "Another Look at the Instrumental-Variable Estimation of Error-Components Models". Journal of Econometrics. 68:29-52.

Beck, Thorsten, Asli Demirguc-Kunt, and Ross Levine (1999). "A New Database on Financial Development and Structure". World Bank Policy Research Department Working Paper No. 2146.

Burnside, Eichenbaum, and Rebelo, forthcoming, "Prospective Deficits and the Asian Currency Crisis," Journal of Political Economy.

Caselli, Francesco, Gerardo Esquivel and Fernando Lefort (1996). "Reopening the Convergence Debate: A New Look at Cross-Country Growth Empirics". Journal of Economic Growth 1: 363-389.

Chen, Shaohua and Martin Ravallion (1997). "What Can New Survey Data Tell Us about Recent Changes in Distribution and Poverty?" The World Bank Economic Review, 11(2):357-382.

Chen, Shaohua and Martin Ravallion (2000). "How Did the World's Poorest Fare in the 1990s?". Manuscript, the World Bank. Data and paper available at http://www.worldbank.org/research/povmonitor/.

Dapice, David, ed. (1995). In Search of the Dragon's Tail: Economic Reform in Vietnam. Cambridge, Mass.: Harvard Institute for International Development/Harvard University Press.

Datt, Gaurav and Martin Ravallion. "When is Growth Pro-Poor?". Manuscript, The World Bank.

Deininger, Klaus and Lyn Squire (1996). "A New Data Set Measuring Income Inequality." The World Bank Economic Review, 10(3):565-591.

Desai, Padma, ed. (1997). Going global: Transition from Plan to Market in the World Economy. MIT Press.

Dollar, David (1992). "Outward-Oriented Developing Countries Really Do Grow More Rapidly: Evidence from 95 LDCs, 1976-85," Economic Development and Cultural Change, April, 523-544. 
(1994). "Macroeconomic Management and the Transition to the Market in Vietnam," Journal of Comparative Economics 18:357-75.

Dollar, David, and Aart Kraay (2001a). "Growth Is Good for the Poor," Policy Research Working Paper No. 2587. The World Bank, Washington, DC.

(2001b), "Trade, Growth, and Poverty," Policy Research Working Paper No.

2615. The World Bank, Washington, DC.

Dollar, David, and Börje Ljunggren (1997). “Vietnam" chapter in Desai, ed.

Easterly, William and Stanley Fischer (2000). "Inflation and the Poor." World Bank Policy Research Department Working Paper No. 2335.

, and Sergio T. Rebelo (1993). "Fiscal Policy and Economic Growth: An Empirical Investigation." Journal of Monetary Economics, (December) 32(3), 417-58.

Fischer, Stanley (1993). "The Role of Macroeconomic Factors in Growth.” Journal of Monetary Economics, (December) 32(3), 485-512.

Frankel, Jeffrey A. and David Romer (1999). "Does Trade Cause Growth?" The American Economic Review, (June) 379-399.

Kaufmann, Daniel, Aart Kraay, and Pablo Zoido-Lobatón (1999). “Governance Matters". World Bank Policy Research Department Working Paper No. 2196.

Knack, Stephen, and Phillip Keefer (1995). "Institutions and Economic Performance: Cross-Country Tests Using Alternative Institutional Measures." Economics and Politics, (November), 7(3), 207-227.

Le Dang Doanh (1994-1995). "Doi Moi in review: A Snapshot of 1994," Vietnam Economic Times, December/January, pp. 18-19.

Levine, Ross, Norman Loayza, and Thorsten Beck (2000). "Financial Intermediation and Growth: Causality and Causes”. Journal of Monetary Economics. 46:31-77.

Ljunggren, Börje, ed. (1993). The Challenge of Reform in Indochina. Cambridge, Mass.: Harvard Institute for International Development/Harvard University Press.

Rodriguez, Francisco and Dani Rodrik (1999). "Trade Policy and Economic Growth: A Skeptic's Guide to the Cross-National Evidence." Mimeo, Department of Economics, University of Maryland.

Romer, Paul (1986). “Increasing Returns and Long-Run Growth." Journal of Political Economy, vol. 94. No. 5. 
(1993). "Idea Gaps and Object Gaps in Economic Development," Journal of Monetary Economics (32).

Sachs, Jeffrey D. and Andrew Warner (1995). "Economic Reform and the Process of Global Integration.” Brookings Papers on Economic Activity, (1), 1-118.

Summers, Robert and Alan Heston (1991). "The Penn World Table (Mark 5): An Expanded Set of International Comparisons, 1950-88." Quarterly Journal of Economics, (May) 106(2), 327-68.

United Nations University - World Institute for Development Economics Research (2000). World Income Inequality Database. Available online at (http://www.wider.unu.edu/wiid/wiid.htm).

de Vylder, Stefan, and Adam Fforde (1996). From Plan to Market: The Transition in Vietnam 1979-1994. Boulder, Co.: Westview. 
Figure 1. Per capita GDP growth rates by decade: rich countries
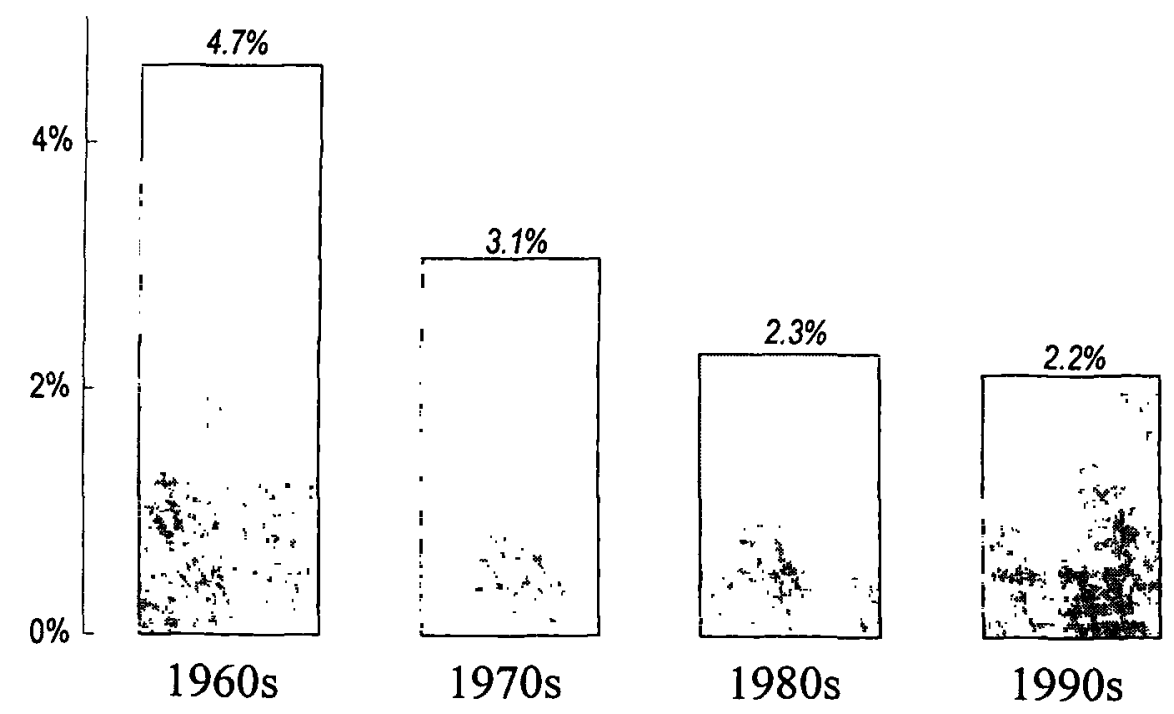

Figure 2. Increase in trade/GDP: 1970 s to 1990 s

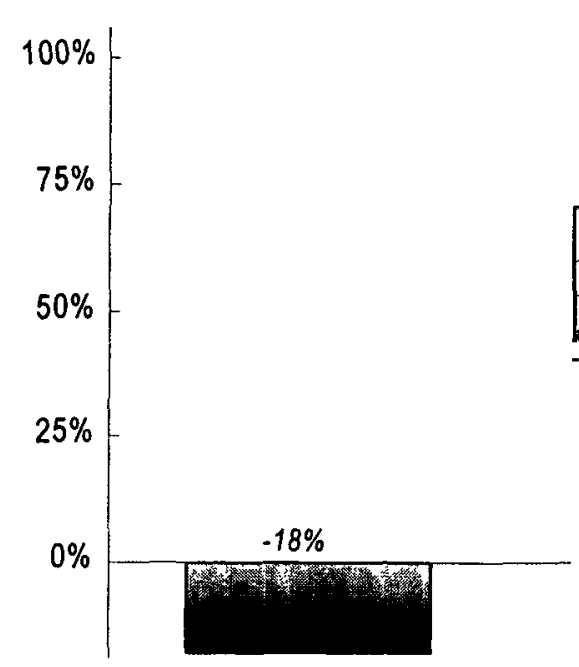

Non-globalizers Rich countries Globalizers 
Figure 3 .

Decline in average import tariffs: $\mathrm{m}$ id $-1980 \mathrm{~s}$ to late-1990s

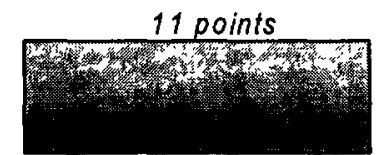

Non-globalizers

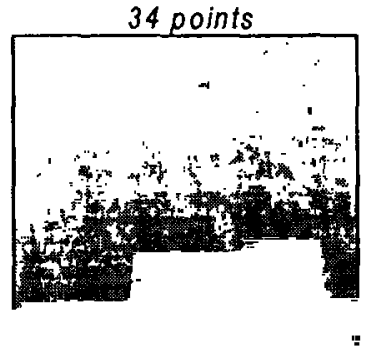

Globalizers

Figure 4. Per capita GDP grow th rates: post-1980 globalizers
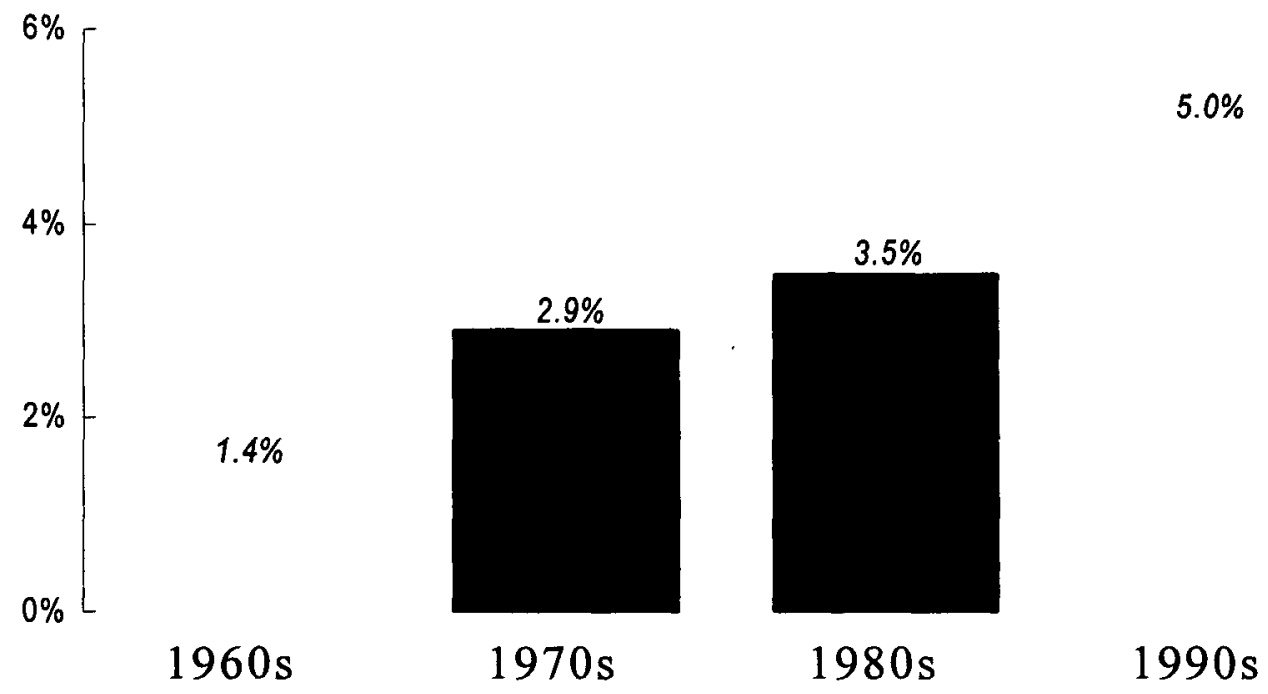
Figure 5. Per capita GDP growth rates: non-globalizers

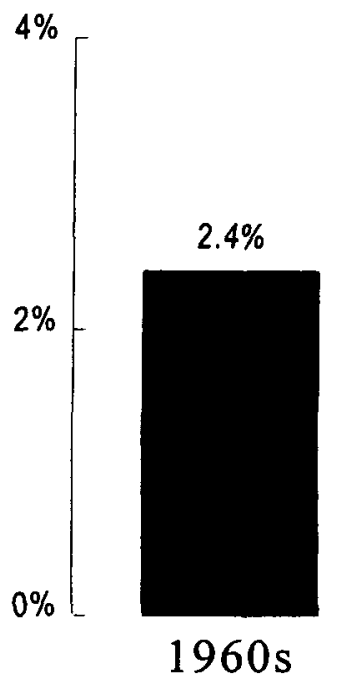

$3.3 \%$

$1.4 \%$

$0.8 \%$

1970s

$1980 \mathrm{~s}$

1990s

Figure 6. Convergence and divergence in the 1990 s (GDP per capita growth rates)
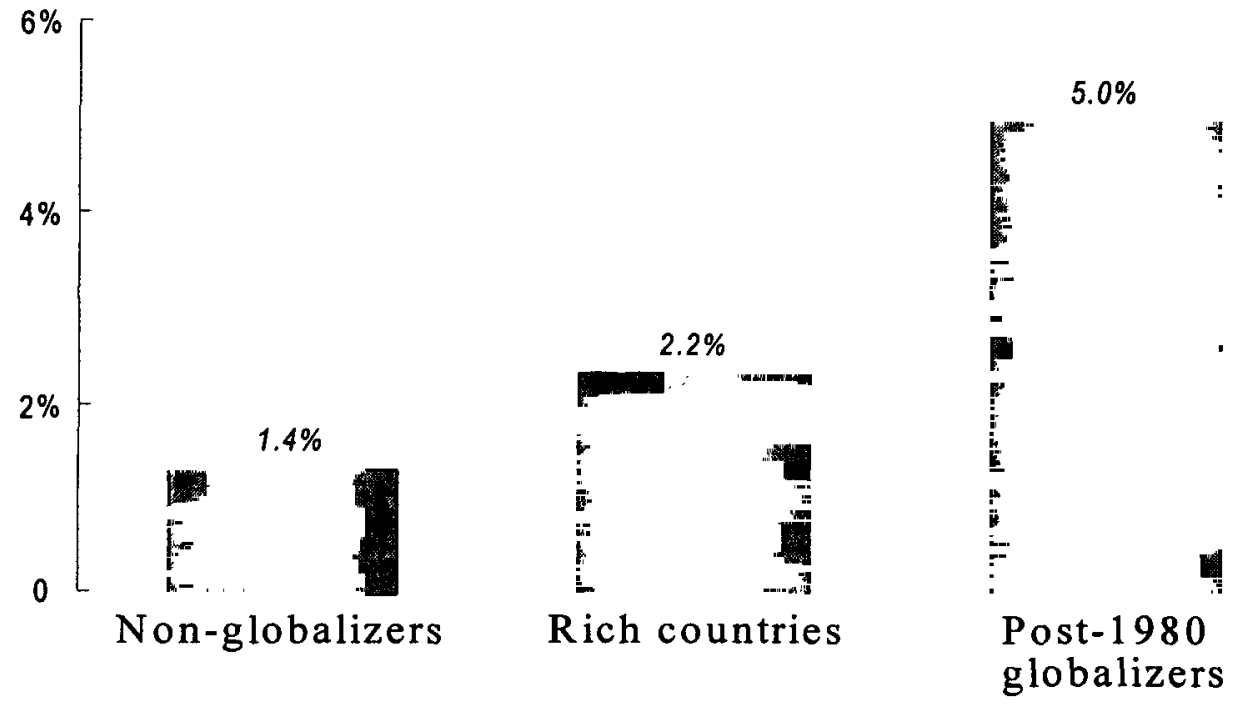
Figure 7.

Growth is good for the poor

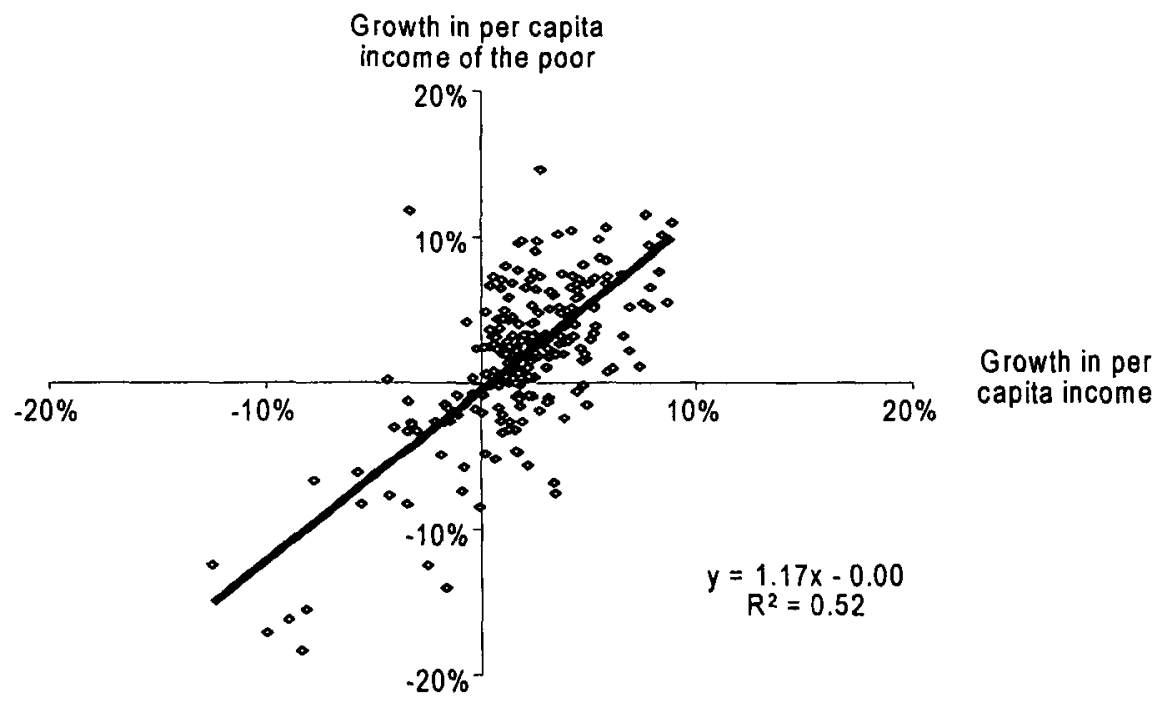

Figure 8.

Increased trade has no correlation with changes in inequality

Change in

Gini coefficient

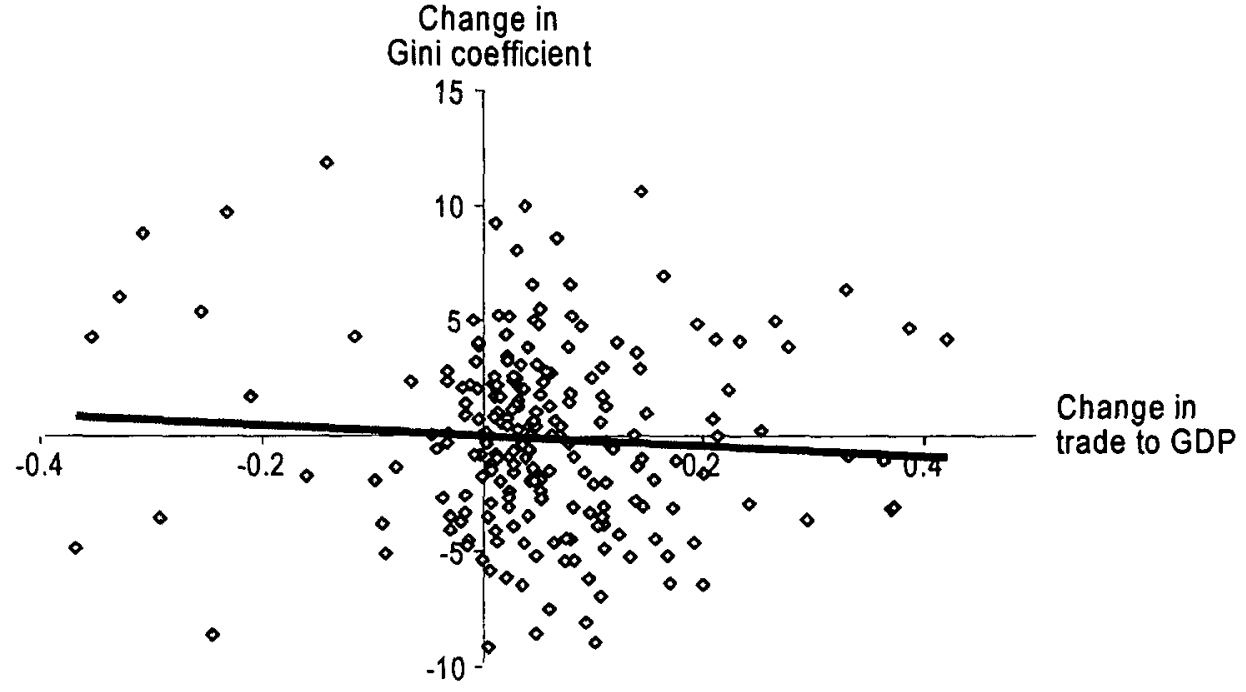


Figure 9. Indicators of Vietnam's reform mid 1980 s to late $1990 \mathrm{~s}$
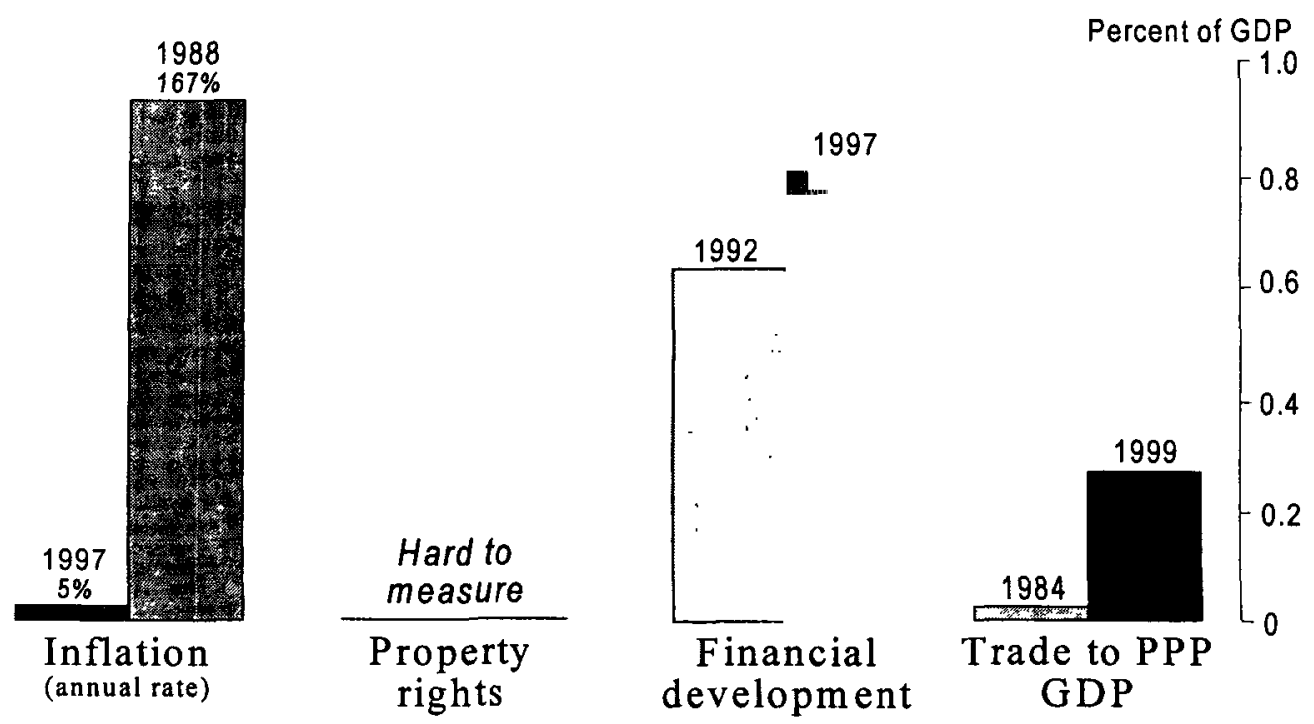

Figure 10

Estimated growth impact of Vietnam's reforms

Trade liberalization

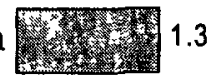

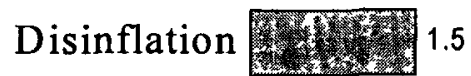

Financial development 1.8

Property rights 2.6

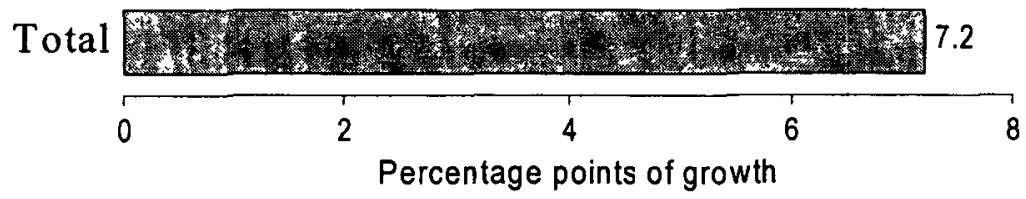




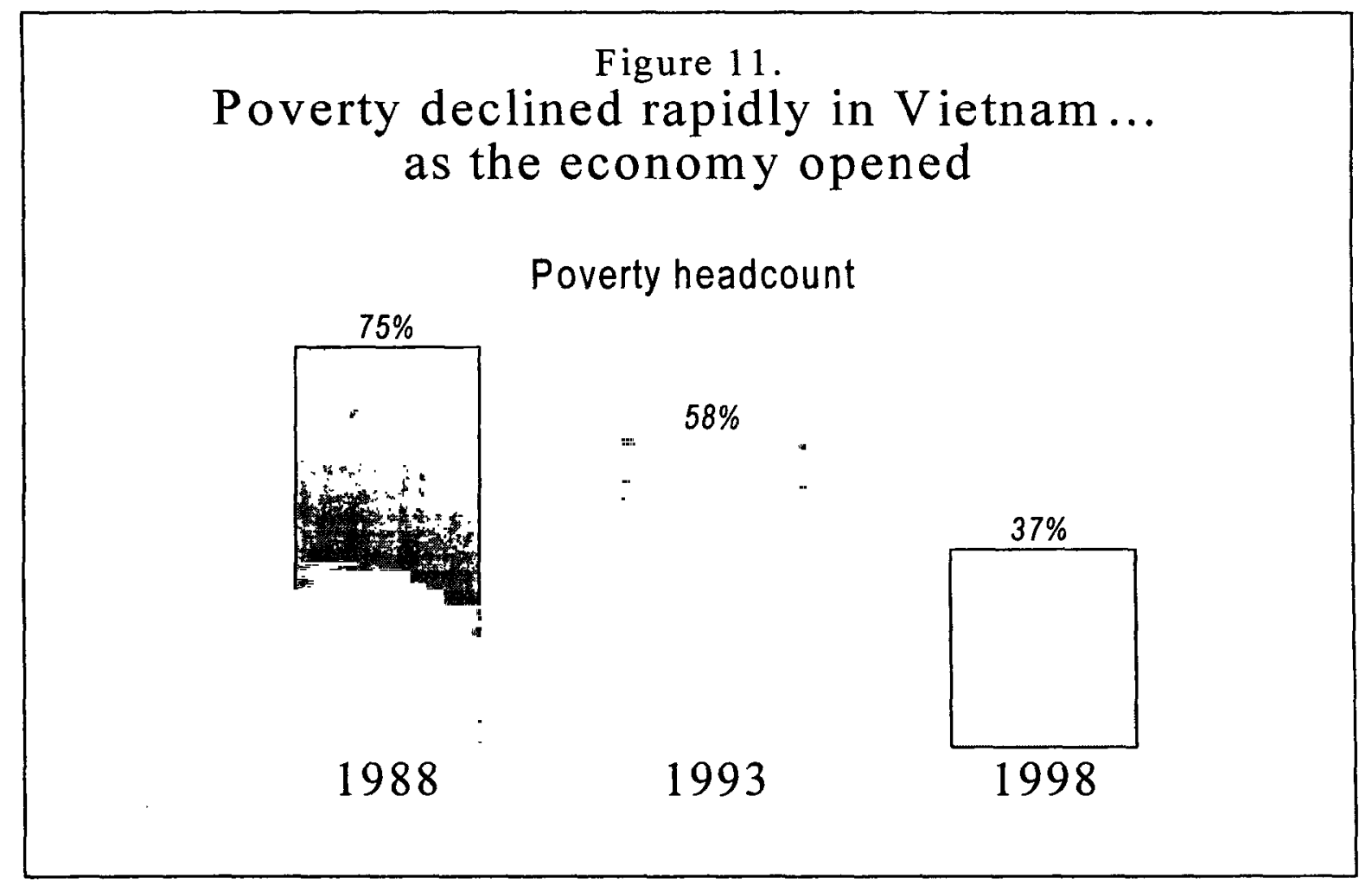

Figure 12. Poverty reduction in India, Vietnam, and China is closely related to the growth rate

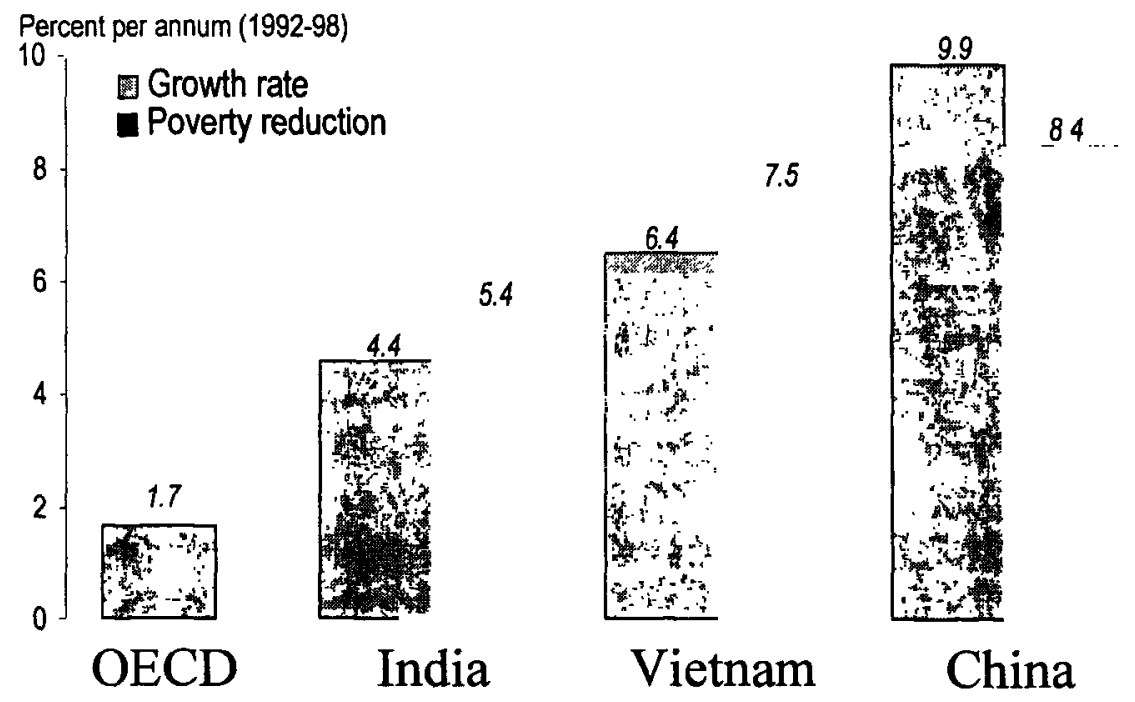


Figure 13. Conditional convergence: without further reform, grow th slows down
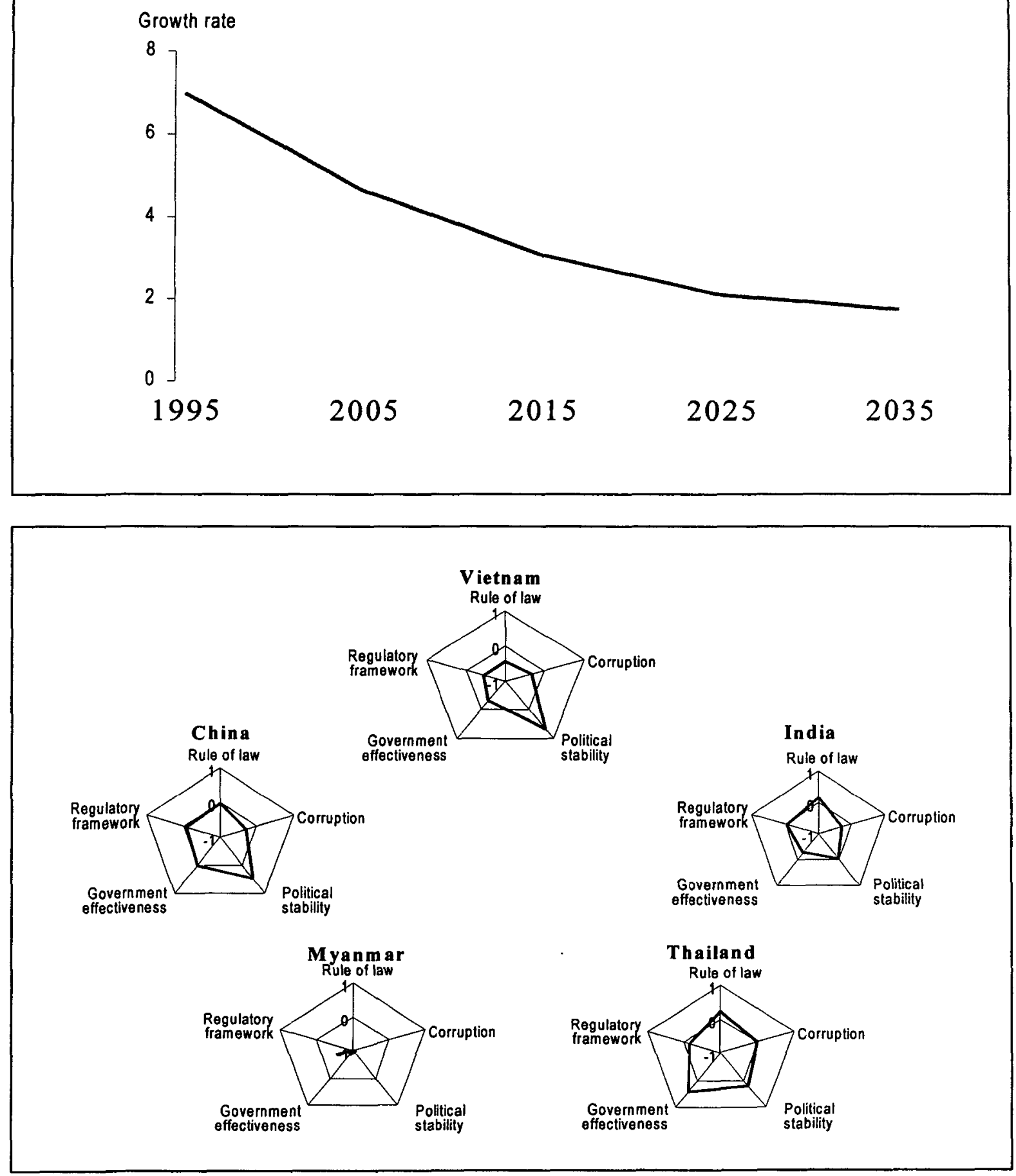


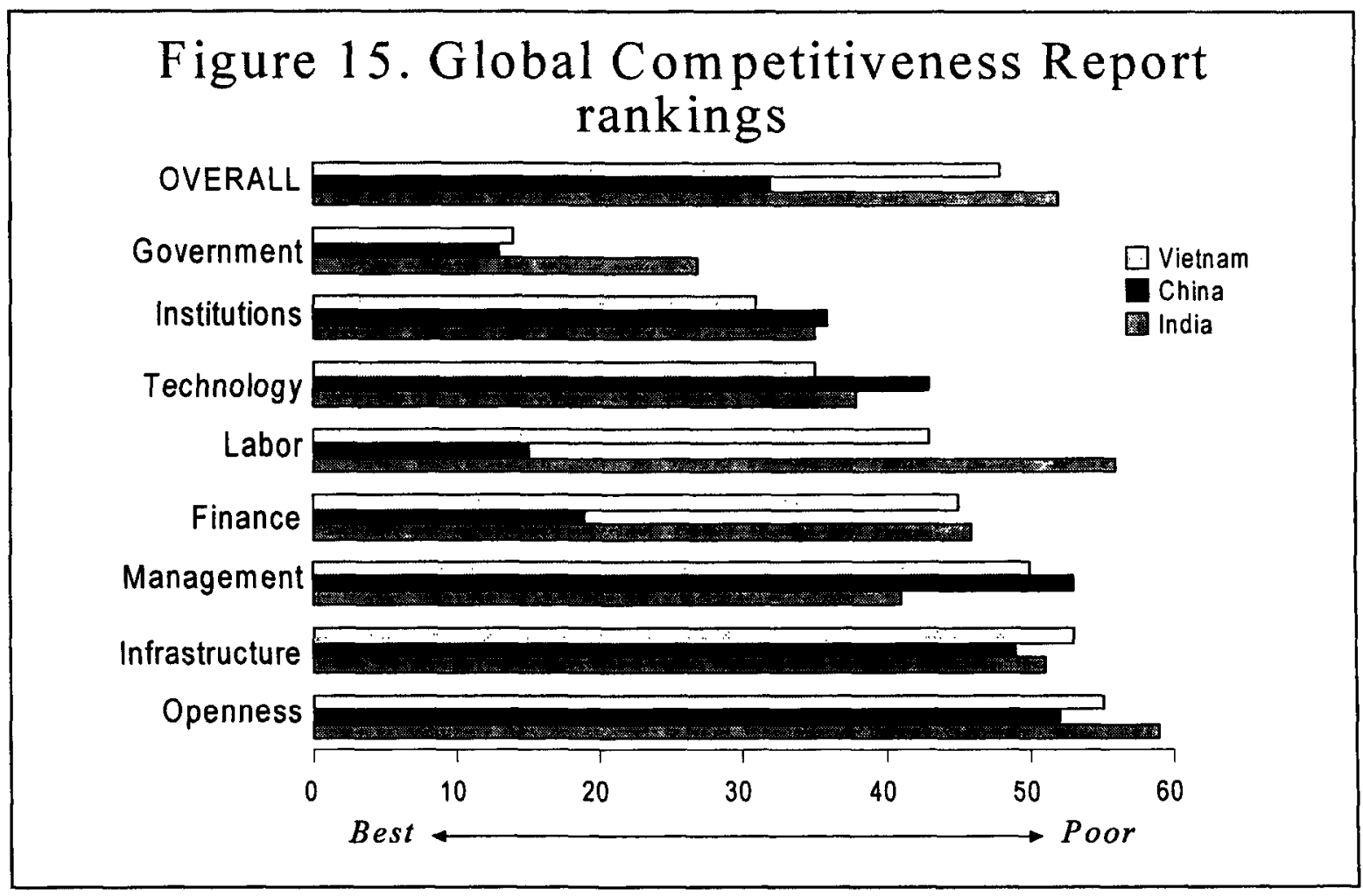

Figure 16. Maritime transport to the U.S. (West Coast): Garments

Costs as share of value of exports
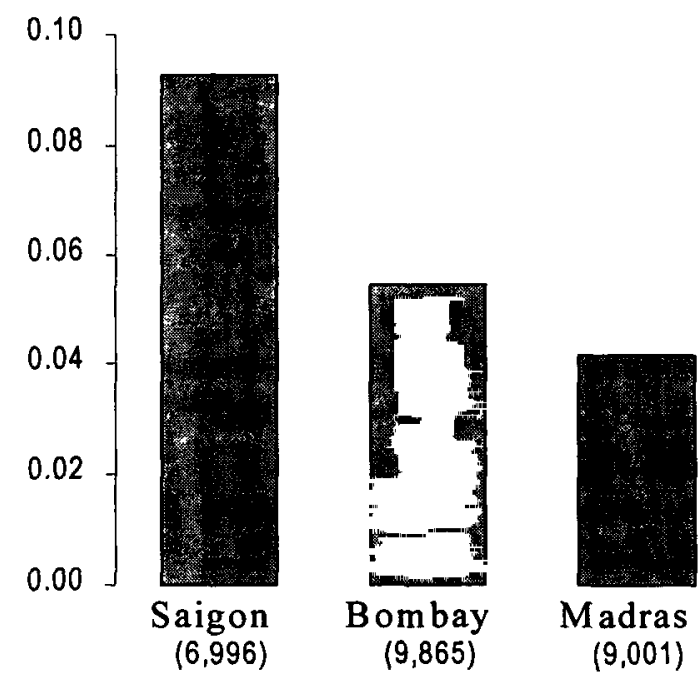

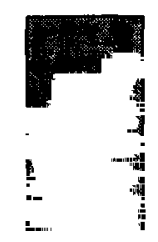

Shanghai $(5,475)$

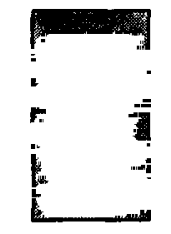

Bangkok $(7,470)$

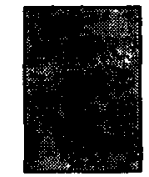

Kao Hsiung $(5,820)$ 


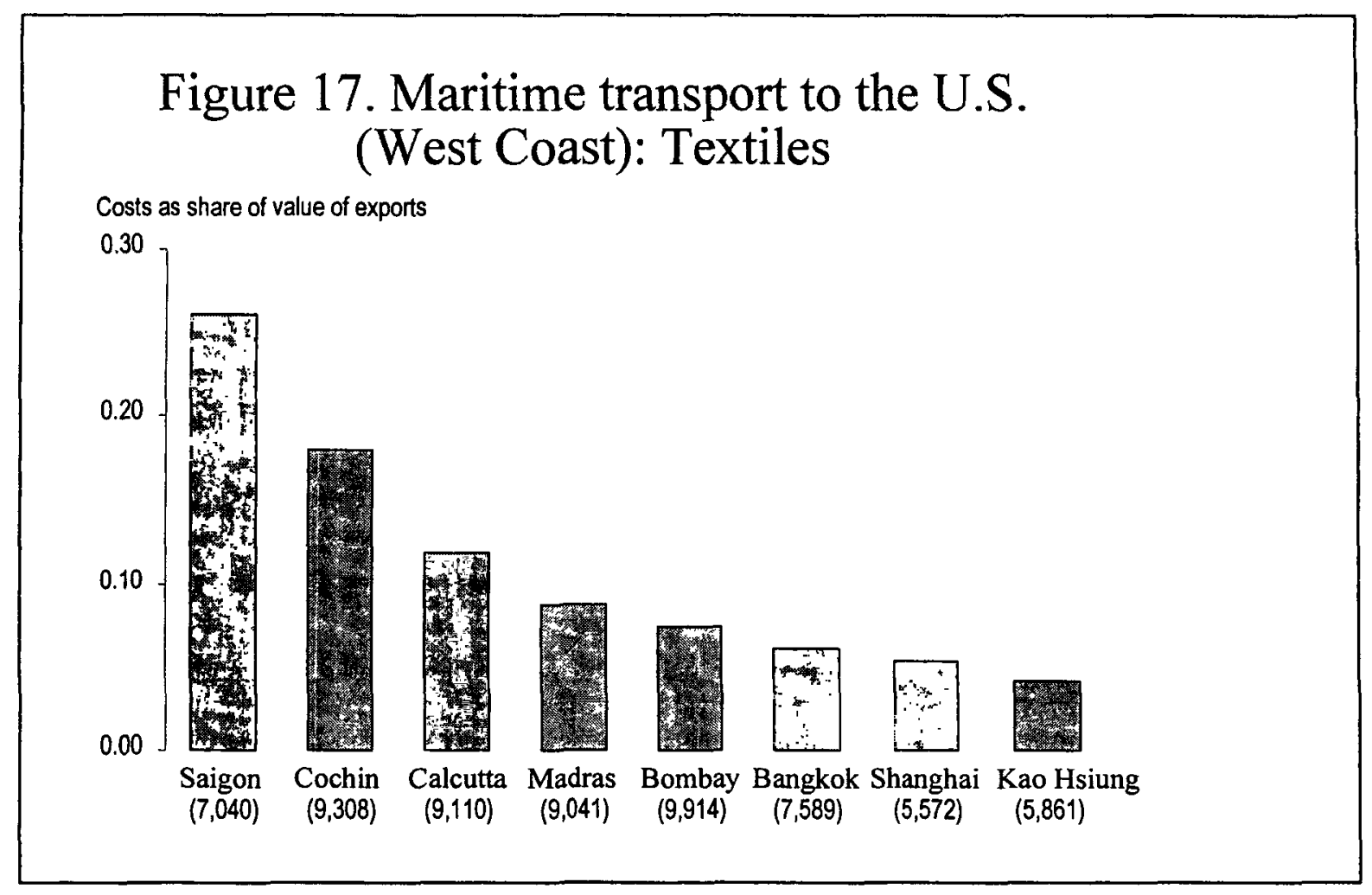

Figure 18. FDI as share of GDP, 1998
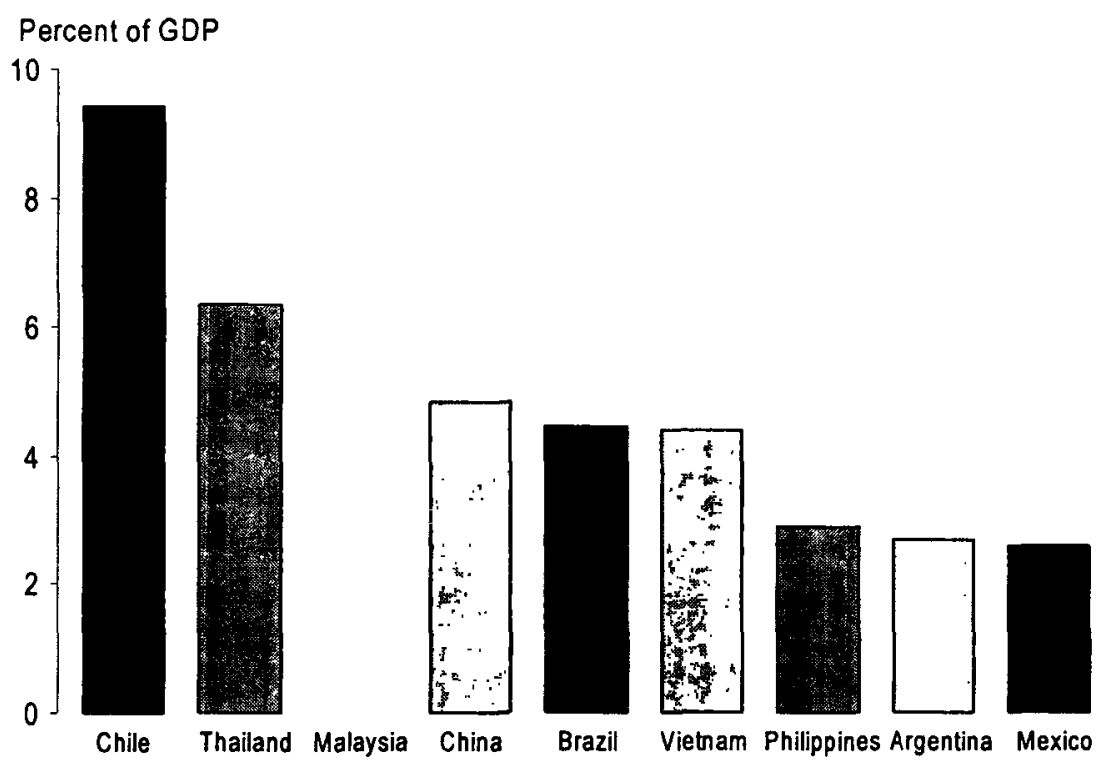

Brazil

Vietnam Philippines Argentina Mexico

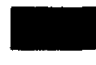

India

Indonesia 


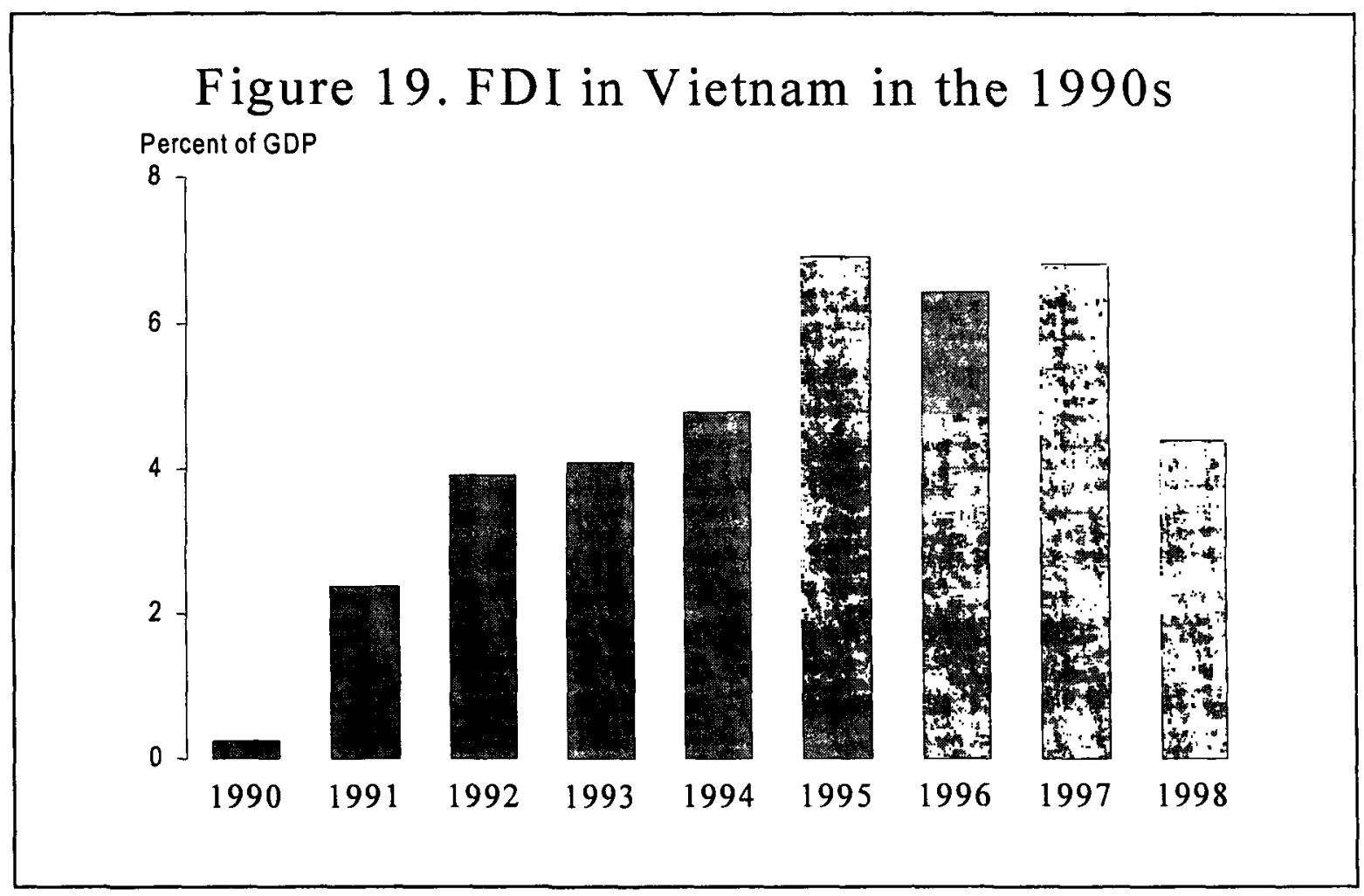





\section{Policy Research Working Paper Series}

Title

WPS2820 The Privatization of the Russian Coal industry: Policies and Proces in the Transformation of a Major Industry

WPS2821 Income, Wealth, and Socialization in Argentina: Provocative Responses from Individuals

WPS2822 An Econometric Analysis of the International Bank for Reconstruction and Development's Creditworthiness

WPS2823 Real Exchange Rate Uncertainty and Private Investment in Developing Countries

WPS2824 Trade Policy and Labor Services: Final Status Options for the West Bank and Gaza

WPS2825 Demand for Imports in Venezuela: A Structural Time Series Approach

WPS2826 Potential GDP Growth in Venezuela: A Structural Time Series Approach

WPS2827 Learning to Export: Evidence from Moroccan Manufacturing

WPS2828 Beyond Oaxaca-Blinder: Accounting for Differences in Household Income Distributions across Countries

WPS2829 The Spatial Distribution of Poverty in Vietnam and the Potential for Targeting

WPS2830 Labor Market Implications of Switching the Currency Peg in a General Equilibrium Model for Lithuania

WPS2831 Health Outcomes in Poor Countries and Policy Options: Empirical Findings from Demographic and Health Surveys

WPS2832 Poverty and Survival Prospects of Vietnamese Children under Doi Moi

WPS2833 School Choice, Student Performance, Emiliana Vegas and Teacher and School Characteristics: The Chilean Case

WPS2834 Investor Protection, Ownership, and the Cost of Capital
Adam Wagstaff

Nga Nguyet Nguyen

Author

Igor Artemiev

Daniel Lederman

David Mckenzie

Luis Servén

Maurice Schiff

Mario A. Cuevas

Mario A. Cuevas

Marcel Fafchamps

Said El Hamine

Albert Zeufack

François Bourguignon

Francisco H. G. Ferreira

Phillippe G. Leite

Nicholas Minot

Bob Baulch

Lodovico Pizzati

Limin Wang

Charles P. Himmelberg R. Glenn Hubbard Inessa Love
Date

Contact for paper

April 2002

V. Joseph 32155

April 2002

P. Soto

37892

April 2002

C. Mendoza 80599

April 2002

P. Soto 37892

April 2002

P. Flewitt 32724

April 2002

M. Geller 85155

April 2002

M. Geller 85155

April 2002

E. Khine 37471

April 2002

$\mathrm{F}$. Bourguignon 31056

April 2002

R. Bonfield 31248

April 2002

L. Pizzati 32259

April 2002

L. Wang 37596

April 2002

H. Sladovich 37698

April 2002

H. Sladovich 37698

April 2002

K. Labrie 31001 
Policy Research Working Paper Series

Title

WPS2835 A Decade of Fiscal Transition

WPS2836 Ethnic Minority Development in Vietnam: A Socioeconomic Perspective
Author

Asad Alam

Mark Sundberg

Bob Baulch

Truong Thi Kim Chuyen Dominique Haughton Jonathan Haughton
Date

May 2002

May 2002
Contact for paper

A. Panton

85433

E. Khine

37471 